\title{
Gene expression phenotypic models that predict the activity of oncogenic pathways
}

E Huang, S Ishida, J Pittmann, H Dressman, A Bild, M Kloos, M D’Amico, R G Pestell, M West \& J R Nevins Nat. Genet. 34, 226-230 (2003).

Figure 3 was reproduced poorly in print. A corrected version appears below.
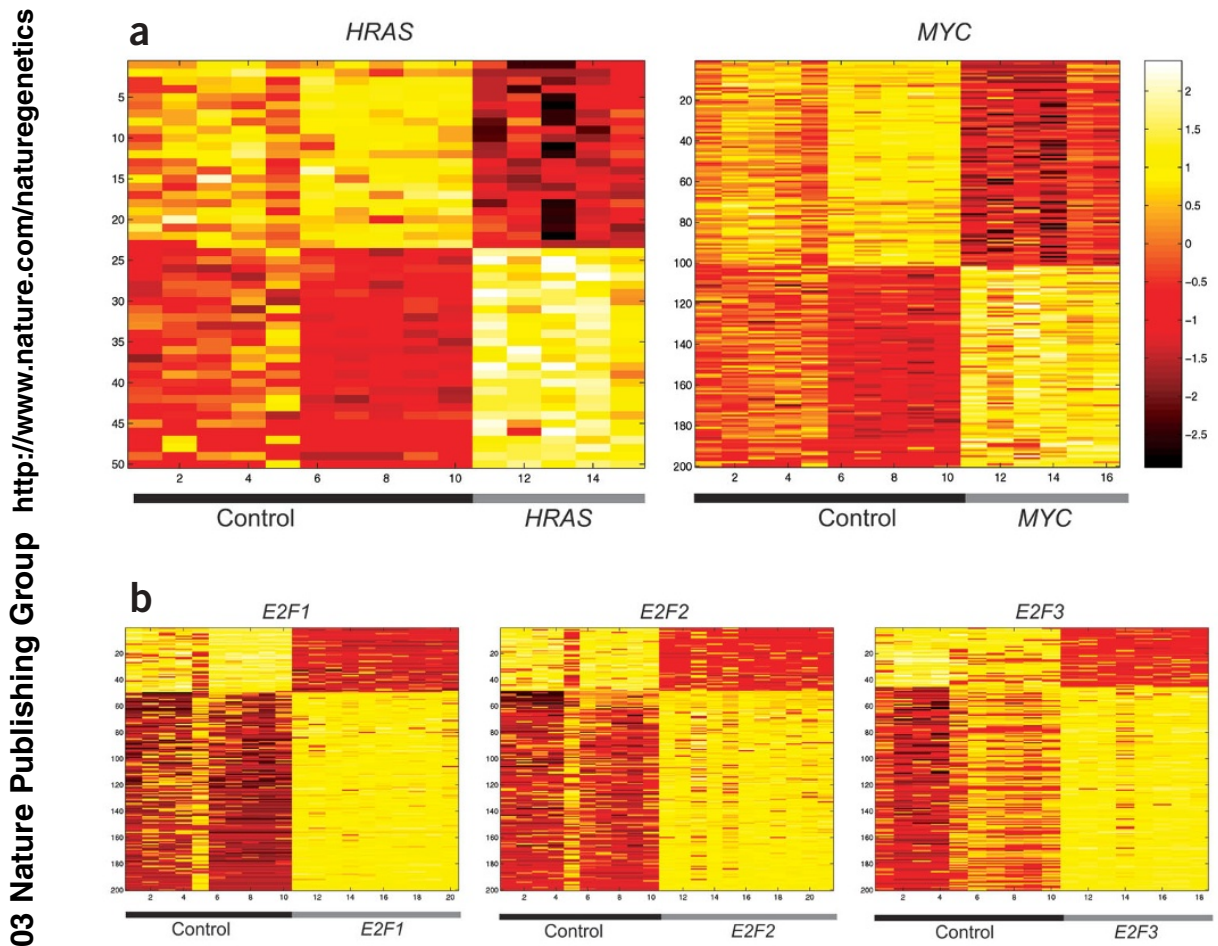